\title{
BUNUH DIRI PADA ANAK DAN REMAJA
}

\author{
SUICIDE IN CHILDREN AND ADOLESCENT
}

Oleh :

Afrina Zulaikha

Nining Febriyana**

* Dokter umum, peserta PPDS 1 Psikiatri Departemen / SMF Ilmu Kedokteran Jiwa FK Universitas Airlangga/RSUD Dr. Soetomo Surabaya.

Alamat korespondensi Jl. Gubeng Airlangga 3/48, Surabaya, Jawa Timur.

Email: dr.afrinazulaikha@gmail.com. HP. 081361740500

** Dokter Spesialis Kedokteran Jiwa/Psikiater (Konsultan), Staf pengajar pada Departemen/SMF Ilmu Kedokteran Jiwa FK Universitas Airlangga/RSUD Dr. Soetomo Surabaya. 


\begin{abstract}
ABSTRAK
Secara global, bunuh diri merupakan penyebab kematian nomor tiga di dunia dengan kecenderungan peningkatan pada kelompok anak dan remaja. Tingkat bunuh diri bervariasi mulai dari ide bunuh diri, ancaman bunuh diri, percobaan bunuh diri dan tindakan bunuh diri. Faktor risiko bunuh diri pada anak dan remaja mencakup gangguan psikiatri, stresor psikososial, faktor kognitif dan faktor biologi. Selain itu bunuh diri pada anak dan remaja juga dipengaruhi oleh perkembangan kognitif, pemahaman mengenai kosep kematian, faktor afektif dan peran kelekatan. Banyak penelitian yang telah mengembangkan alat penapisan bunuh diri seperti Ask Suicide Screening Question (ASQ) dan Risk for Suicide Quessionare (RSQ), dan lainnya yang dapat digunakan sebagai langkah preventif untuk mengurangi dan membantu anak dan remaja yang berisiko untuk melakukan bunuh diri. Pengetahuan dan pemahaman (psikodinamika) yang baik serta komprehensif tentang bunuh diri pada anak dan remaja akan sangat membantu dalam melakukan prevensi dan intervensi yang tepat dalam penanganan kasus ini.
\end{abstract}

Kata kunci: bunuh diri, konsep kematian, perkembangan kognitif, anak, remaja.

\begin{abstract}
Suicide is the third leading cause of death in the world with an increasing trend in children and adolescent. Suicide rate varied from suicidal ideation, suicide threats, suicide attempts and completed suicide. Risk factors for suicide in children and adolescent includes psychiatric disorders, psychosocial stressors, cognitive factors and biological factors. Suicide in children and adolescent also affected by cognitive developmental, understanding of death concepts, afective components and role of attachment. Many studies have developed suicide screening tools such as Ask Suicide Screening Question (ASQ) and Risk for Suicide Quessionare (RSQ) and others that can be used as a preventive measure to reduce and help children and adolescent who are at risk of committing suicide. Comprehensive knowledge and understanding of suicide in children and adolescent will be usefull on giving appropiate intervention and preventive of this case.
\end{abstract}

Keywords : suicide, death concept, cognitive developmental, children, adolescent. 


\section{Pendahuluan}

Bunuh diri merupakan masalah kesehatan yang menjadi perhatian utama di banyak negara terutama pada kelompok anak-anak dan usia paruh baya (Wasserman et al.2005). Pada tahun 2012, WHO mengungkapkan bunuh diri merupakan penyebab kematian nomor dua terbanyak pada kelompok usia 15-29 tahun (WHO, 2016).

Di Indonesia belum ada data secara nasional mengenai kejadian bunuh diri pada anak dan remaja. Namun berdasarkan data pada tahun 2012, WHO memperkirakan kejadian bunuh diri di Indonesia adalah 4,3\% per 100.000 populasi (WHO, 2012). Kemudian Badan Penelitian dan Pengembangan Kesehatan Kemenkes RI pada tahun 2014 melakukan penelitian ekstrapolasi dan menunjukkan angka kejadian bunuh diri di Indonesia adalah 1,77 per 100.000 penduduk (Depkes, 2016). Komisi Nasional Perlindungan Anak (KPAI) pada tahun 2014 melaporkan ada 89 kasus bunuh diri pada anak dan remaja. Sembilan kasus pada rentang usia 5 sampai 10 tahun. Sementara 12 hingga 15 tahun ada 39 kasus. Sedangkan yang berusia di atas 15 tahun ada 27 kasus.

\section{Bunuh Diri pada Anak dan Remaja}

\section{Anak dan Remaja}

Menurut WHO, batasan usia anak adalah sejak anak di dalam kandungan sampai usia 19 tahun. Remaja merupakan periode transisi dari masa kanak-kanak ke masa dewasa yang ditandai dengan percepatan perkembangan fisik, mental, emosional, dan sosial. WHO mengatakan remaja adalah bila anak telah mencapai umur 10-19 tahun (Dhamayanti, 2013).

\section{Bunuh Diri}

Bunuh diri adalah usaha tindakan atau pikiran yang bertujuan untuk mengakhiri hidup yang dilakukan dengan sengaja, mulai dari pikiran pasif tentang bunuh diri sampai akhirnya benar-benar melakukan tindakan yang mematikan. Keparahan tingkat bunuh diri bervariasi, mulai dari ide bunuh diri, ancaman bunuh diri, percobaan bunuh diri, dan melakukan bunuh diri (completed suicide). Ide bunuh diri yaitu pemikiran untuk membunuh diri sendiri; membuat rencana kapan, dimana, dan bagaimana bunuh diri akan dilakukan; dan pemikiran tentang efek bunuh dirinya terhadap orang lain. Ancaman bunuh diri merupakan ungkapan yang ditujukan kepada orang lain yang mengindikasikan keinginan untuk melakukan bunuh diri. Sedangkan percobaan bunuh diri/parasuicide didefinisikan sebagai semua tindakan melukai diri sendiri dengan hasil yang tidak fatal dengan tujuan untuk mencari perhatian, dan keinginan untuk menjadikan bunuh diri sebagai penyebab kematian yang tercantum pada sertifikat kematian atas dirinya (Rathus dan Miller, 2002; Pelkonen dan Marttunen, 2003; Orden et al., 2011). 


\section{Epidemiologi}

National Centre for Health Statistic (NCHS) tahun 2000 mengungkapkan data angka bunuh diri di AS dari segi usia, pada usia 10-14 tahun adalah 1,6/100.000, sedangkan usia 15-19 tahun 9,5/100.000. Berdasarkan jenis kelamin, anak laki-laki 3 kali lebih sering melakukan bunuh diri dibandingkan anak perempuan, namun seiring bertambah usia ratio semakin bertambah menjadi 4,5: 1 pada usia 15-19 tahun. Percobaan bunuh diri pada remaja 2 kali lipat lebih sering pada perempuan dibandingkan laki-laki. Sedangkan ide bunuh diri sering dijumpai pada pelajar SMA, kira-kira 1 dari 4 perempuan, dan 1 dari 6 laki-laki (AACAP, 2001; Cash dan Bridge, 2009).

Metode bunuh diri pada remaja yang paling sering digunakan adalah dengan menggunakan senjata api. Pada percobaan bunuh diri, metode yang paling sering digunakan adalah menelan analgetik, selain itu metode lain yang sering digunakan adalah mengiris permukaan pergelangan tangan atau leher (AACAP, 2001; Gould dan Kramer, 2001; Shain dan Care, 2007; Cash dan Bridge, 2009).

Pada anak, bunuh diri bersifat impulsif dan metode yang digunakan adalah menabrakkan diri, lompat dari tempat yang tinggi dan menjatuhkan diri dari tangga (Hoberman dan Garfinkel, 1988; Shaffer et al., 1996; Dervic, Brent dan Oquendo, 2008).

\section{Faktor Resiko}

Gangguan psikiatri yang sering menjadi faktor resiko bunuh diri pada anak dan remaja adalah gangguan suasana perasaan (depresi dan bipolar), skizofrenia, penyalahgunaan zat, gangguan tingkah laku, dan gangguan makan (Apter dan Freudstein, 2000; Gould dan Kramer, 2001; Shain dan Care, 2007).

Faktor resiko lain yang juga bisa memunculkan perilaku bunuh diri yaitu adanya kejadian yang menimbulkan stres, masalah hubungan anak dan orangtua, perceraian orangtua, riwayat keluarga, dan penyakit kronis (Shafii et al., 1985; Gould et al., 1996; Pfeffer, 2000; Gould dan Kramer, 2001; Sofronoff, Dagliesh dan Kosky, 2005; Gray dan Dihigo, 2015).

Keputusasaan serta kemampuan meyelesaikan masalah yang buruk juga dihubungkan dengan perilaku bunuh diri. Perilaku bunuh diri dijumpai diantara pasien dengan range IQ retardasi mental sedang atau di atasnya dan lebih sering dijumpai pada remaja dibandingkan anak-anak (Gould dan Kramer, 2001; Sofronoff, Dagliesh dan Kosky, 2005).

Dari aspek biologi, pada pemeriksaan single-photon emission tomography (SPET) didapati pasien yang dengan sengaja menyakiti diri memiliki penurunan kadar ikatan reseptor 5-HT2a. Pada remaja korban bunuh diri juga dijumpai disregulasi posreseptor 5HT2a, yang ditandai dengan perubahan ikatan protein $\mathrm{C}$ kinase. Penurunan kadar triptopan di dalam darah dijumpai pada anak prepubertal dengan masalah psikiatri yang melakukan usaha percobaan bunuh diri dibandingkan dengan anak yang normal atau anak dengan masalah psikiatri yang memiliki ide bunuh diri. Sehingga kadar triptopan darah dapat dijadikan penanda untuk mengidentifikasi anak-anak dengan resiko bunuh diri. Beberapa penelitian mengungkapkan keterkaitan kadar serum kolesterol yang rendah dengan bunuh diri pada pasien depresi 
dan anak. Sedangkan bunuh diri pada remaja menunjukkan kadar serum kolesterol yang lebih tinggi. Pada pemeriksaan elektroensefalogram (EEG) didapati alfa asimetris pada regio posterior dikaitkan dengan keinginan bunuh diri. Oleh karena itu penurunan aktivasi posterior berkaitan dengan bunuh diri dan atau perilaku agresif (Pfeffer, 2000; King dan Apter, 2003).

\section{Instrumen Pemeriksaan}

Masih sedikit penelitian mengenai apakah penapisan rutin resiko bunuh diri pada anak di bawah usia 12 tahun dibutuhkan. Walaupun US Preventative Services Task Force (UPSTSF) tidak menganjurkan penapisan rutin pada anak usia 7-11 tahun, tetapi mereka merekomendasikan penapisan untuk Major Depresive Disorder (MDD) pada usia berapapun. Jika didapati anak tersebut memiliki 1 atau lebih dari 4 faktor resiko berikut ini : 1. Psikopatologi orang tua, 2. Memiliki pengalaman negatif selama hidupnya, 3. Komorbid dengan kondisi medis kronis, 4. Komorbid dengan gangguan jiwa, maka anak-anak dengan faktor resiko seperti ini memiliki resiko munculnya psikopatologi atau melakukan bunuh diri walaupun tidak didapati adanya MDD (Heise, York and Thatcher, 2016).

Alat penapisan resiko bunuh diri telah dikembangkan dan digunakan pada pasien anak dan remaja. Berikut ini beberapa diantaranya : Ask Suicide Screening Question(ASQ), Risk for Suicide Quessionare (RSQ), The Mood and Feeling Quessionare (MFQ), Treatment Emergen Activation and Suicidality Assessment Profile (TEASAP), Columbia Suicide Severity Ratting Scale (C-SSRS), Suicide Behaviour Quessionaire (SBQ-R), Suicidal Ideation Quessionaire (SIQ) (Gray dan Dihigo, 2015; Heise, York dan Thatcher, 2016).

Skala self-administered bunuh diri sangat berguna untuk menyaring pasien normal dan yang memiliki resiko tinggi bunuh diri. Tetapi tetap tidak bisa menggantikan dengan penilaian klinis, dan skala penapisan memiliki kecenderungan terlalu sensitif dan kurang spesifik. Seorang anak atau remaja yang memiliki hasil positif dari uji penapisan harus dinilai lagi secara klinis. Kebanyakan tes belum dinilai secara adekuat terhadap populasi anak dan remaja (Gray dan Dihigo, 2015).

\section{Terapis}

Penanganan awal yang dapat diberikan adalah krisis intervensi yang bertujuan untuk memberikan pengalaman yang baik antara keluarga dan staf medik gawat darurat, mengatur harapan realistis tentang follow up treatment, dan mendapatkan komitmen dari remaja yang bunuh diri serta keluarganya untuk kembali dan melakukan evaluasi lebih lanjut.

Pelaku percobaan bunuh diri harus dirawat inap jika kondisinya tidak stabil dan perilakunya tidak bisa diprediksi. Gambaran diagnostik yang bisa digunakan sebagai indikasi untuk rawat inap adalah depresi mayor dengan gejala psikotik, siklus cepat perilaku impulsif dan iritabel, psikotik dengan halusinasi perintah dan penyalahgunaan alkohol dan zat terlarang (AACAP, 2001).

Penanganan selanjutnya dilakukan menggunakan teknik psikoterapi yang bertujuan untuk mengurangi perasaan tidak berdaya, marah, cemas, putus asa, serta untuk mereorientasi perspektif 
kognitif dan emosional dari anak/remaja yang melakukan bunuh diri. Jenis-jenis psikoterapi yang dapat digunakan yaitu terapi perilaku kognitif, psikoterapi interpersonal, dialectical behavioral therapy (DBT), psikoterapi psikodinamik dan terapi keluarga (Rathus dan Miller, 2002; Calear et al., 2015).

Psikofarmakologi diberikan berdasarkan gangguan yang mendasari perilaku bunuh diri. Pelaku bunuh diri yang memiliki riwayat gangguan bipolar, pertama kali harus diberikan mood stabilizer sebelum mendapatkan anti depresan, dan lithium merupakan pengobatan lini pertama. SSRI dipilih sebagai penatalaksanaan depresi pada anak dan remaja. Obat antidepresan golongan trisiklik harus dihindari karena efek yang mematikan (Pfeffer, 2000; Baron et al., 2009).

\section{Pencegahan}

Pencegahan bunuh diri sangat penting dan direkomendasikan untuk strategi pengembangan dan penerapan penurunan angka bunuh diri. Pencegahan primer yaitu program dalam latar pendidikan, meliputi Program Berbasis Sekolah, Krisis Hotline, Pembatasan Metode yang Mematikan, Edukasi melalui Media serta Mengidentifikasi Anak dan Remaja dengan Faktor Resiko Tinggi Bunuh Diri. Pencegahan sekunder berkaitan dengan mengidentifikasi dan penatalaksanaan yang adekuat terhadap mereka yang memilki risiko bunuh diri, berupa penatalaksanaan psikososial dan penatalaksanaan secara biologi dengan pemberian antidepresan (AACAP, 2001; Pelkonen dan Marttunen, 2003).

Pencegahan tersier bertujuan mengembangkan penatalaksanaan yang tepat untuk anak dan remaja, khususnya modalitas terapi yang tepat setelah melakukan percobaan bunuh diri, sehingga dapat mencegah terjadinya bunuh diri (AACAP, 2001; Pelkonen dan Marttunen, 2003).

Postvention adalah istilah yang digunakan untuk menjelaskan intervensi yang dilakukan setelah terjadi bunuh diri. Setelah anak atau remaja melakukan bunuh diri, sangat dianjurkan untuk melakukan krisis intervensi pada orang-orang terdekatnya karena mereka berisiko menderita depresi, gangguan stres paska trauma atau reaksi duka cita yang patologis. Bila hal ini tidak dilakukan, maka jumlah kejadian bunuh diri pada kerabat dan orang terdekat pelaku selama setahun setelah kejadian bunuh diri akan meningkat (AACAP, 2001; Gould dan Kramer, 2001; Pelkonen dan Marttunen, 2003).

\section{Psikodinamika bunuh diri pada anak dan remaja}

Bunuh diri pada anak sangat terkait dengan perkembangan kognitif dan pemahaman tentang kematian, stressor psikososial, afektif, serta peran kelekatan (attachment). Untuk mengerti psikodinamika mengenai hal ini maka akan dibahas teori kognitif Piaget, terutama tahap preoperasional, dan konkret operasional yang erat kaitannya dengan pemahaman anak mengenai konsep kematian yang disertai juga tentang subkonsep kematian yang diusulkan oleh Speece dan Brent (Mishara, 1999; Gould dan Kramer, 2001; Slaughter, 2015). 


\section{Teori Perkembangan Kognitif}

Menurut Piaget, anak mengalami empat tahap utama dalam memperoleh pengetahuan, yaitu sensori motor, preoperasional, konkret operasional dan formal operasional. Setiap tahapan ini berurutan tetapi tidak kaku dan setiap tahap saling terintegrasi dengan tahap sebelumnya. Tahap sensori motor (0-2 tahun) dimulai sesaat setelah bayi lahir dengan adanya aksi sensori dan motorik yang terus berkembang melalui proses pengulangan sehingga membentuk skema yang stabil atau perilaku berurutan yang membentuk dasar struktur dan fungsi intelektual. Pada tahap ini, anak belum berpikir tentang kematian (Richardson, 2003).

Tahap pre-operasional (2-7 tahun) terdiri dari dua tahap, yaitu berpikir pre-konseptual (2-4 tahun) dan berpikir intuitif (4-7 tahun). Pada tahap ini anak meyakini semua fenomena fisik yang ada di dunia ini dihasilkan oleh manusia dan akan digunakan untuk kepentingan manusia. Anak juga percaya mereka bisa membuat benda mematuhi keinginan mereka, dan bisa mengontrol benda melalui pikiran atau aksinya (Boyle, 1976). Pada tahap ini anak memandang kematian sebagai bagian dari kehidupan, dan kematian diartikan sebagai tidur atau keberangkatan, bertahap dan bersifat sementara. Pemahaman ini muncul oleh karena mereka belum mencapai pemahaman kognitif mengenai konsep waktu. Anak berpikir jika mereka berteriak dengan kencang memanggil orang yang sudah meninggal, maka orang tersebut dapat bangun kembali (Boyle, 1976; Poltorak dan Glazer, 2006; Hunter dan Smith, 2008; Slaughter, 2015).

Tahap konkret Operasional (7-11 tahun), pada tahap ini anak sudah mampu menggunakan logika berpikir, sudah bisa memahami sudut pandang orang lain dan kemampuan sosial juga sudah berkembang. Berbeda dengan tahap pre-operasional yang belum mengetahui konsep waktu. Tahap awal fase ini, anak akan mulai memahami bahwa kematian merupakan suatu akhir, dan menyadari hal tersebut tidak bisa dikembalikan. Mereka juga mulai memahami hubungan sebab akibat, seperti hubungan antara sakit dengan kematian serta paham jika kematian merupakan fenomena universal yang terjadi pada semua manusia, tetapi anak belum mengerti bahwa kematian tidak dapat dielakkan dan masih berpikir jika kematian bisa dihindari bila seseorang cukup pintar atau beruntung. Anak yang bunuh diri pada usia ini mengalami distorsi mengenai konsep kematian. Mereka memandang kematian orang lain sebagai hal yang pasti dan final sedangkan kematian diri mereka sendiri dipandang sebagai suatu bentuk proses kehidupan lebih lanjut setelah kematian. Sedangkan pada usia 10-12 tahun anak dengan perilaku bunuh diri percaya bahwa setelah mati masih ada proses kehidupan yang terus berlanjut (seperti tidur, merasa, gerakan motorik) dibanding dengan anak normal atau agresif. Terakhir tahap formal operasional, pada tahap ini anak sudah mampu berpikir abstrak dan sudah memiliki penalaran secara ilmiah. Konsep kematian pada anak sudah sama seperti pada orang dewasa, yaitu merupakan hal yang tidak dapat dielakkan, bersifat universal dan merupakan fase akhir dari siklus kehidupan yang ditandai dengan hilangnya fungsi organ-organ tubuh (Poltorak dan Glazer, 2006; Hunter dan Smith, 2008; Slaughter, 2015; Stambrook dan Parker, 2016). 


\section{Afektif}

Kebanyakan perilaku bunuh diri muncul karena keinginan untuk melarikan diri dari perasaan yang tidak tertahankan, seperti dendam, isolasi sosial, atau kebencian. Perasaan kehilangan memainkan peranan yang penting sebagai faktor pencetus langsung bunuh diri pada remaja, baik kehilangan yang akut ataupun kehilangan yang sudah terakumulasi. Istilah "kehilangan" disini digunakan untuk menunjukkan kehilangan karena kematian atau perpisahan yang permanen (misalnya, perceraian orangtua) yang mengakibatkan kerenggangan atau hilangnya figur yang dicintai (King, 2003).

\section{Peran Kelekatan (attachment)}

Ada tiga jenis kelekatan menurut Ainsworth. Pertama kelekatan yang secure, anak yang secure memiliki setidaknya satu orang teman dekat yang dapat dipercaya dan memiliki hubungan yang berfokus pada solusi ketika menghadapi masalah. Kedua insecure-ambivalent, anak dengan riwayat seperti ini mudah frustrasi, sangat cemas, hubungan sosial yang kurang bagus dan tidak berdaya. Terakhir, kelekatan yang bersifat insecure-avoidant, anak dengan riwayat kelekatan seperti ini gagal untuk memulai interaksi dan mencari orang lain pada saat mendapatkan ancaman (King, 2003).

Berdasarkan tipe kelekatan dan konsep-konsep yang terkait masalah kehidupan yang dihubungkan dengan depresi, terdapat dua tipe kerentanan terhadap depresi, yaitu dependent dan selfcritical. Subtipe dependent mempunyai pola kelekatan insecure-ambivalent, yang diakibatkan oleh pola asuh orang tua yang lalai atau yang sangat menuruti keinginan anak. Sedangkan subtipe selfcritical mempunyai ciri ketergantungan yang berlebihan, tidak mementingkan hubungan dekat tetapi terpreokupasi dengan masalah harga diri dan otonomi. Hal ini diakibatkan oleh pola asuh orang tua yang terlalu mengontrol, menolak, menghakimi atau sering menghukum (King, 2003).

Remaja dengan masalah kejiwaan, derajat self-critical atau dependent berkaitan erat dengan munculnya ide atau usaha bunuh diri. Pada pribadi yang dependent, depresi lebih disebabkan oleh kejadian-kejadian interpersonal yang negatif seperti kehilangan atau penolakan. Tindakan bunuh diri yang dilakukan cenderung impulsif, manipulatif dan tidak fatal dalam melakukan usaha percobaan bunuh diri. Sebaliknya, pada self-critical depresi lebih disebabkan oleh perasaan akibat gagal dalam mencapai sesuatu atau target yang diinginkan, kekecewaan narsisistik, seperti perasaan terhina, dan terancam. Pada tipe ini usaha percobaan bunuh diri yang dilakukan bersifat terencana dan serius (King, 2003).

Kelekatan juga berperan dalam proses pengaturan diri, perlindungan diri dan proses penenangan diri. Kelekatan yang secure mampu menimbulkan memori yang tetap ada didalam diri anak walaupun orang tua tidak hadir secara fisik. Sebaliknya pada insecure, anak merasa asing dan memusuhi dirinya serta tidak mencintai tubuhnya. Hal ini dapat menjadi faktor resiko untuk bunuh diri (King, 2003).

Pada masa remaja, kelekatan terhadap persahabatan dan percintaan menjadi sarana pembentukkan kelekatan lain selain dengan keluarga. Kelekatan remaja terhadap keluarganya yang bersifat ambivalen, memiliki kecenderungan untuk beralih ke teman dan pasangannya dengan 
menggantikan peran orang tua, tetapi hal ini sering tidak berjalan dengan baik karena mengulang pola ambivalensi yang sama sehingga sangat rentan mengalami kekecewaan berulang (King, 2003).

\section{Kesimpulan}

Angka bunuh diri yang semakin meningkat pada kalangan anak dan remaja membutuhkan perhatian serius. Pengetahuan dan pemahaman yang baik terhadap faktor risiko bunuh diri pada anak dan remaja serta tindakan pencegahan yang komprehensif dan tepat sasaran diharapkan dapat menurunkan angka bunuh diri.

\section{Daftar Pustaka}

1. AACAP (2001) 'Practice Parameter for the Assessment and Treatment of Children and Adolescents With Suicidal Behavior', J Am ACAD Child Adolesc Psychiatry, 40(7).

2. Apter, A. and Freudstein, O. (2000) 'Adolescent Suicidal Behaviour : Psychiatric Populations', in Hawton, K. and Heeringen, K. Van (eds) Suicide and Attempted Suicide The International Handbook of Suicide and Attempted Suicide. 2nd edn. Chichester: John Wiley \& Sons, LTD, pp. 261-273.

3. Baron, D. et al. (2009) 'Suicide in teens and young adults in the United States', Quaderni Italiani di Psichiatria, 28(3), pp. 96-101. doi: 10.1016/j.quip.2009.04.004.

4. Boyle, D. (1976) A Students $\hat{a} \epsilon^{T M}$ Guide to Piaget. 3rd edn. Great Britain: Pergamon Press.

5. Calear, A. L. et al. (2015) 'A systematic review of psychosocial suicide prevention interventions for youth', European Child \& Adolescent Psychiatry. Springer Berlin Heidelberg. doi: 10.1007/s00787-015-0783-4.

6. Cash, S. J. and Bridge, J. A. (2009) 'Epidemiology of Youth Suicide and Suicidal Behavior', Curr Opin Pediatr, 21(5), pp. 613-619. doi: 10.1097/MOP.0b013e32833063e1. Epidemiology.

7. Dervic, K., Brent, D. A. and Oquendo, M. A. (2008) 'Completed Suicide in Childhood', Psychiatric Clinics of North America, 31, pp. 271-291. doi: 10.1016/j.psc.2008.01.006.

8. Dhamayanti, M. (2013) Overview Adolescent Health Problems and Services, Indonesian Pediatric Association. Available at: www.idai.or.id/artikel/seputar-kesehatan-anak/overviewadolescents-health-problems-and-ser vices.

9. Gould, M. S. et al. (1996) 'Psychosocial Risk Factors of Child and Adolescent Completed Suicide', Arc Gen Psychiatry, 53, pp. 1155-1162.

10. Gould, M. S. and Kramer, R. A. (2001) 'Youth Suicide Prevention', The American Association of Suicidology, 31, pp. 6-11.

11. Gray, B. P. and Dihigo, S. K. (2015) 'Suicide risk assessment in high-risk adolescents', The 
Nurse Practitioner, 40(9), pp. 30-37.

12. Heise, B., York, A. and Thatcher, B. (2016) 'Child Suicide Screening Methods : Are We Asking the Right Questions?', The Journal of Nurse Practitioners, 12(6), pp. 410-417.

13. Hoberman, H. M. and Garfinkel, B. D. (1988) 'Completed Suicide in Children and Adolescents', J Am ACAD Child Adolesc Psychiatry. The American Academy of Child and Adolescent Psychiatry, 27(6), pp. 689-695. doi: 10.1097/00004583-198811000-00004.

14. Hunter, S. B. and Smith, D. E. (2008) 'Predictors of Children's Understandings of Death: Age, Cognitive Ability, Death Experience and Maternal Communicative Competence', OMEGA, 57(2), pp. 143-162. doi: 10.2190/OM.57.2.b.

15. King, R. A. (2003) 'Psychodinamic approaches to youth suicide', in King, R. A. and Apter, A. (eds) Suicide in Children and Adolescents. Cambridge: Cambridge University Press, pp. $150-169$.

16. King, R. A. and Apter, A. (2003) Suicide in Children and Adolescents. Cambridge: Cambridge University Press.

17. Mishara, B. L. (1999) 'Conceptions of Death and Suicide in Children Ages 6-12 and Their Implications for Suicide Prevention', The American Association of Suicidology, 29(2), pp. $105-118$.

18. Orden, K. A. Van et al. (2011) 'The Interpersonal Theory of Suicide', Psychol Rev, 117(2), pp. 575-600. doi: 10.1037/a0018697.The.

19. Pelkonen, M. and Marttunen, M. (2003) 'Child and Adolescent Suicide Epidemiology, Risk Factors, and Approaches to Prevention', Pediatr Drugs, 5(4), pp. 243-263.

20. Pfeffer, C. R. (2000) 'Suicidal Behaviour in Children: an Emphasis on Developmental Influences', in Hawton, K. and Heeringen, K. Van (eds) Suicide and Attempted Suicide The International Handbook of Suicide and Attempted Suicide. 2nd edn. Chic: John Wiley \& Sons, LTD, pp. 237-248.

21. Poltorak, D. Y. and Glazer, J. P. (2006) 'The Development of Children's Understanding of Death: Cognitive and Psychodynamic Considerations', Child and Adolescent Psychiatric Clinics of North America, 15, pp. 567-573. doi: 10.1016/j.chc.2006.03.003.

22. Rathus, J. H. and Miller, A. L. (2002) 'Dialectical Behavior Therapy Adapted for Suicidal Adolescents', Suicidal and Life-Threatening Behavior, 32(2), pp. 146-157.

23. Richardson, K. (2003) Models of Cognitive Development. 2nd edn. East Sussex: Psychology Press.

24. Shaffer, D. et al. (1996) 'Psychiatric Diagnosis in Child and Adolescent Suicide', Arch Gen Psychiatry, 53, pp. 339-348.

25. Shafii, M. et al. (1985) 'Psychological Autopsy of Completed Suicide in Children and Adolescent', Am J Psychiatry, 142(September), pp. 1061-1064.

26. Shain, B. N. and Care, P. (2007) 'Suicide and Suicide Attempts in Adolescents', American 
Academic of Pediatrics, 120(3), pp. 669-676. doi: 10.1542/peds.2007-1908.

27. Slaughter, V. (2015) 'Young children's understanding of death', The Australian Psychology Society, 40(July), pp. 179-186. doi: 10.1080/00050060500243426.

28. Sofronoff, K., Dagliesh, L. and Kosky, R. (2005) Out of Options: A Cognitive Model of Adolescent Suicide and Risk Taking. Cambridge: Cambridge University Press.

29. Stambrook, M. and Parker, K. C. H. (2016) 'The Development of the Concept of Death in Childhood: A Review of the Literature', JSTOR, 33(2), pp. 133-157. Available at: www.jstor.org/stable/23086325. 